\title{
Honour and Shame in Women's Sports
}

\author{
Katie Liston \\ School of Sport, Ulster University \\ Newtownabbey, Northern Ireland
}

(C) Katie Liston. This work is licensed under the Creative Commons Attribution-NonCommercial-

NoDerivatives 4.0 International License. To view a copy of this license, visit

http://creativecommons.org/licenses/by-nc-nd/4.0/.

\begin{abstract}
This piece, first delivered as a keynote address, examines the role of honour and shame in understanding the many stories of women's involvement in sport in Ireland from the eighteenth century onwards, and especially in the modern era. While women's sporting involvement was regarded as shameful, especially in those sports imbued with traditional associated masculine norms, the prospect for women's sports is different today than in the past. Yet the struggle for honour is ongoing, seen in topical debates concerning gender quotas and the recommendations made by the Citizens Assembly on gender equality. Bringing the analysis up to date, the piece outlines hoc policy initiatives around gender equality in sport from the mid-2000s (in which the author was centrally involved) to the publication of the first formal statutory policy on women in sport, in 2019. Here it is argued that the guilt and shame of previous generations has influenced the public debate on gender quotas and it is as if, in the desire for perceived equality, the current generation of sportswomen do not wish to be associated with quotas. In this way, honour is conflated with merit. The piece concludes by suggesting that merit is honourable, personally, but equally, quotas are by no means shameful in public struggles.
\end{abstract}

Keywords: Women; Sport; Honour; Shame; Gender; Policy; Quotas; Ireland

This piece was first presented as the keynote address at the conference, Sidelines, Tramlines and Hemlines: Women in Irish Sport, held in Dundalk in February 2020, some two weeks before the global pandemic hit the shores of the UK and Ireland. Here, the content has been edited to account for publishing conventions and updated in light of events since, and it has been adjusted for reading purposes. It maintains the overall structure, emphasis and tone of the presentation delivered in Dundalk.

Taking a relatively detached sociological perspective, this piece seeks to examine the role of honour and shame in understanding the many stories, well-known and less known, of women's involvement in sport in Ireland from the eighteenth century onwards, but especially in the modern era. Many of these stories are often rendered less visible or even invisible: not because women are not or have not been involved in sport. Rather, women's experiences were and are omitted ${ }^{1}$ : neglected from women's history, from sports studies and from wider social commentaries. Taking a longer-term historical perspective, there has never been a time, from the dawn of our civilisation to the present, when women have been as involved as men in sports, as participants, or as spectators. While it is historically true that sports have usually been more important for males, equally however, there has never been a time when girls and women were

\footnotetext{
${ }^{1}$ Allen Guttmann, Women's Sports: A History (Columbia University Press: New York and Oxford, 1991).
} 
totally excluded from sports, and there have certainly been times and places where their involvement was almost as extensive and intensive as men's. ${ }^{2}$ Let us examine some preVictorian examples in order to better understand the legacy underpinning the growing involvement of women in sport today. For these historical threads bind us: to yet undiscovered pasts, to stories from women in previous generations, to the diversity and heterogeneity of women's involvement in sport, leisure and lifestyles on the island of Ireland, and to a range of possible futures.

\section{Pre-Victorian sport}

British sports history ${ }^{3}$ notes the Marchioness of Salisbury and others riding to the hounds well into her dotage, it is said, and the achievements of Elizabeth Stokes (formerly Wilkinson), the self-proclaimed European Championess of boxing in the early eighteenth century. ${ }^{4}$ It is claimed that she married fellow pugilist bare-knuckle boxer, James Stokes, and the two were often challenged as a pair. In other words, female and male bouts took place, often including rounds of sword fighting and wrestling. From an Irish perspective, on Saturday 1 October 1726, the British Gazetteer advertised a bout (in issue 74) between Stokes and Irishwoman Mary Welch at the Bear Garden amphitheatre in London, owned by James Figg, the famed pugilist of the time.

Mary Welch's statement in the Gazetteer was as follows:

I, Mary Welch, from the Kingdom of Ireland, being taught, and knowing the Noble Science of Defence, and thought to be the only Female of this Kind in Europe, understanding here is one on this Kingdom, who has exercised on the publick Stage several Times, which is Mrs. Stokes, who is stiled the famous Championess of England; I do hereby invite her to meet me, and exercise the usual Weapons practiced on the Stage, at her own Amphitheatre, doubting not, but to let her and the worthy Spectators fee, that my Judgement and Courage is beyond hers. ${ }^{5}$

Stokes replied in the same advertisement, saying:

I Elizabeth Stokes, of the famous City of London, being well known by the Name of the Invincible City Championess for my Abilities and Judgement in the abovesaid Science; having never engaged with any of my own Sex but I always came off with Victory and Applause, shall make no Apology for accepting the Challenge of this Irish Heroine, not doubting but to maintain the Reputation I have hitherto established, and shew my Country, that the Content of it's (sic) honour, is not ill entrusted in the present Battle with their Championess.

A note at the bottom explained that 'they fight in cloth jackets, short petticoats, coming just below the knee, Holland drawers, white stockings and pumps'.

Some weeks later in the same paper, dated 22 October, and at what was said to be the particular desire of a great number of noblemen, Welch invited Stokes to meet her a second time. In this public advertisement, Welch appeared to offer a second bout because 'having engaged with Mrs Stokes, and thought to have given convincing Proofs of my skill being equal, or rather superior to her's (sic), in the Noble Science of Defence; but since hearing that several Disputes have arose concerning our last Engagement, and that it is reported the Cut which Mrs Stokes received then, was not given by the Judgement of the Sword'. Stokes accepted this second challenge, saying in the same public advertisement: 'I ... shall make no Apology for myself, but that I willingly accept this second Challenge, as it is the Desire of several Gentlemen, and,

\footnotetext{
${ }^{2}$ Guttmann, Women's Sport.

${ }^{3}$ Carl Cone, (ed.), Hounds in the Morning (University Press of Kentucky: Lexington, 1981).

${ }^{4}$ Malissa Smith, A History of Women's Boxing (Rowman \& Littlefield: Plymouth, 2014).

${ }^{5}$ The British Gazetteer, October 1, 1726.
} 
being the last Time of my appearing upon the Stage, I make no doubt of behaving myself after such a Manner, that will gain me Applause, and, I hope, give Satisfaction to the Spectators'. Welch accepted other challenges too, for example, from Elizabeth Bedford in April 1727.

The rivarly between Welch and Stokes was played out in public in the coming years. The challenge was issued again by Welch, with her partner Robert Barker, to Mrs Stokes and her partner, William Gill, on 17 June 1727 in the British Gazeteer. Then, Welch noted that 'this battle has been some considerable Time in agitation'. The men were to fight in Holland drawers, white stockings and pumps and the women in white drawers, and short Dimity petticoats, white stockings and pumps. Judging by a later report on 1 July, it was James and Elizabeth Stokes who fought Welch and Barker. Responding to further public challenge from Welch, the Stokes' 'were of the Opinion that by our former Performances, we had established to ourselves such a Reputation, as would effectually have secured us from the Trouble of any more Hibernian Challenges, but findings these Concomitants (as they call themselves) in the Pursuit of Fame, are not susceptible of any Conviction of their Insufficiency to stand in Competition with us'. It is also said that one Felix MacGuire fought at Figgs' amphitheatre with his wife Letitia in 1733, part of the broader outworking of Irish emigration to London, that inflamed anti-Catholic sentiment and suspicion, and rumours that Irish workers were undercutting English builders. ${ }^{6}$ This culminated in the Spitalfields riots in 1736. Historian Chris Thrasher ${ }^{7}$ argues that Elizabeth Stokes was deliberately erased in favour of her male contemporary, James Figg, commonly cited as 'the father of boxing', but according to Thrasher, she was the more popular of the two during their lifetime.

Yet to be connected are other eighteenth-century threads beyond this sport, and these examples, into the leisure and physical culture lives of women of the period: Letitia MacGuire, Mary Welch, Mary Waller and Bonduca O'Brien were also swordswomen who fought with sharp weapons, including broadswords, rapiers and daggers for prize money. The dangerous nature of these swordfights involving Welch and others is illustrated by the following firsthand account from a letter of the period:

Their weapons were a sort of two-handed sword, three or three and a half feet in length ... the blade was about three inches wide ...that part cut like a razor ... On either side of the two amazons a man stood by, holding a long staff, ready to separate them should blood flow. After a time, the combat became very animated, and was conducted with force and vigour. The Irishwoman presently received a great cut across her forehead, and that put a stop to the first part of the combat. The ... third combat was fought for some time without result, but the poor Irishwoman was destined to be the loser, for she received a long and deep wound all across her neck and throat. The surgeon sewed it up, but she was too badly hurt to fight any more. ${ }^{8}$

Approximately 100 years later, working-class women competed in six-day bicycle races while the capacity to manage menstruation, conceive and give birth was debated by doctors, who were generally more concerned with medicalising middle-class patients. Today Katie Taylor is now world leading as a professional boxer, and yet, at the same time, formal equality does not exist in her sport. PhD researcher, Deirdre Nelson, is nearing completion, at Ulster University, of her comparative analysis of the legal regulation of gender equality in boxing in the USA and UK. She took her own legal case against the Boxing Union of Ireland (BUI) in 1999. Denied the chance to box professionally, she challenged the decision in an Industrial Tribunal and won

\footnotetext{
${ }^{6}$ L. A. Jennings, She's a Knockout!: A History of Women in Fighting Sports (Rowman \& Littlefield: London, 2015).

${ }^{7}$ Chris Thrasher, "Disappearance: How shifting gendered boundaries motivated the removal of eighteenth century boxing champion Elizabeth Wilkinson from historical memory," Past Imperfect, 18 (2012). Available at https://doi.org/10.21971/P7SK56.

${ }^{8}$ Ben Miller, Irish Swordsmanship (Hudson Society Press: New York, 2018), 145-194.
} 
her case ${ }^{9}$ the tribunal holding that the BUI's refusal to consider her application to box on medical grounds was not proportionate but was premised on 'gender-based assumptions and stereotypes'. ${ }^{10}$ The BUI's policy then, which was not 'to entertain any application from a female boxer seeking permission to box within its jurisdiction until the European Boxing Union had reached some agreement on the ... matter of medical supervision', ${ }^{11}$ was held to have contravened sections of the 1977 Employment Equality Act, and was also regarded as disproportionate as it affected all women who wanted to box.

Thus, the interplay between social and legal issues persists in modern boxing, a sport that played, and still plays, a central role in the maintenance of hegemonic notions of masculinity. Regulatory arguments have also been used by boxing organisations to deny women the right to hold professional boxing licences; e.g., in the US a contact-sport exemption was enshrined in Title IX legislation, which was a critical factor in the mutually reinforcing cycle between opportunity to box and interest in women's boxing. This position now appears to run contrary to the widespread attention since given to Taylor's successes as World Champion.

As many writers have acknowledged, if we cannot know and remember the past - with all of the challenges this brings - we will likely repeat it, unknowingly perhaps. ${ }^{12}$ This is especially the case for our collective sporting past which, as Guttman noted, was not a homogeneous whole. In stepping away from the important, and oftentimes fascinating detail of, stories about women in sport, it is possible, indeed beneficial, to also hover above these, in a role more akin to an observer. This permits insights into the ways in which women's involvement in sport throughout the ages, especially their physicality, is bound up with changing patterns of honour and shame, for any analysis of sportswomen that is devoid of social context is a study out of focus.

\section{Honour and Shame: Bedfellows for Women in Sport}

Consider the honour of being a female swordfighter or duellist in the 1700s; the shame that had to be negotiated of showing one's body in swimming costumes in the early 1900s; and even the public disgrace that was bestowed on Maeve Kyle, pictured in the cover page of this issue, who as a young mother, became the first female track and field athlete to represent Ireland in the 1956 Olympics. A letter to the editor of the Irish Times in September of that year condemned her selection: a sports field was no place for a woman, was the claim, and her selection was 'most unbecoming, unseemly and degrading of womenfolk. It must not be countenanced on any grounds'. According to Kyle, this was signed Vox Populi (or voice of the people). ${ }^{13}$ Kyle herself has recounted more of this treatment, as did her daughter Shauna to me, who often accompanied her on training runs, Maeve running, and Shauna on her bicycle. Indeed, the inspiration for the cover of this special issue is inspired by a photo of the two. Maeve received abuse, shaming and objects were even thrown at her. Kyle was a noted international hockey player in her right, but athletics was then much less acceptable for women. Implicit in this were ethno-religious tensions too: Kyle was not only criticised for being a young mother, leaving her daughter to go to the 1956 Melbourne Olympics, where she was the Olympic team flagbearer, but she was also from an Irish Protestant heritage, born in Kilkenny,

\footnotetext{
9 "Woman boxer wins legal fight," Irish Times, June 28, 2001.

${ }^{10}$ Deirdre Nelson vs Boxing Union of Ireland (2001) Dec-E/2001/18, para. 6.12.

${ }^{11}$ Deirdre Nelson vs Boxing Union of Ireland (2001), para. 6.11.

${ }^{12}$ George Santayana, The Life of Reason: Reason in Common Sense (Harvard University Press: Cambridge, 1905).

${ }^{13}$ Brian Boyd, "An Olympic suffragette: 'I was seen to be off gallivanting in a foreign land,'” Irish Times, August 11, 2012.
} 
studied in Dublin (at Old Alexandra and Trinity Colleges) and married into a prominent unionist family in a County Antrim town dominated by unionist politics.

Kyle's shaming was by no means culturally unique, however. For example, en route to Melbourne at a training camp in California, her sprint action was recorded by an American Professor of Physical Education to show American girls that track athletics was not unfeminine, that they too could be graceful and attractive. ${ }^{14}$ Some twenty years later, in the 1972 Olympics, Mary Peters won gold for Great Britain and Northern Ireland in the pentathlon. She was widely celebrated for her achievement, then and today, receiving the oldest and highest honour of chivalry in 2019, the Order of the Garter. Only a small number outside the aristocracy are invited onto this list, which dates back centuries. She too recounted to me her awareness then, and now, of the social mores around women's physicality and femininity in the 1970s, especially when she began to lift heavier weights, and her body shape changed. What is it then about women in sport that touches so deeply on the shared social consciousness of what is regarded as honourable or shameful? For these are part of the intricate connection between the pattern of our own lives and the course of history.

Honour is about the integration or standing of the person within society. As the work of Tom Inglis exemplifies, ${ }^{15}$ it has both an individual and social dimension. It is an estimation that a person has about their self-worth, but this has to be matched against society's evaluation. Honour is identifiable when people say, or do, good things about or for you. Receiving honour makes one feel proud, but if honour is undermined, or even questioned or attacked in some way, one feels ashamed. Personal honour comes from behaviour: achieved through adhering to conventions, norms and values. It is built on engagement in normative behaviour: staying within the boundaries of accepted social codes, laws and morals. For women, there is a distinctive embodied dimension. In relations of shame and honour, women construct their sense of what appropriate behaviour entails, and they negotiate their choices, if not the boundaries of acceptability themselves.

Honour came from a variety of sources in everyday life in 1970s and 1980s Ireland, north and south: from the way people greeted each other, the way they spoke, dressed or walked or held themselves. Think of Maeve Kyle, running on a Sunday morning, the Lord's Day, in a tracksuit, stopped by a man out walking his dog and then questioned by him as to what she thought she was doing. She retorted in her own indomitable style because this event did occur: 'the same as you, but much quicker'. ${ }^{16}$ This was sufficient in that micro-situation to push back on the offence that she supposedly had committed. Think of Mary Peters lifting weights designed first for male body builders and the questions this raised about femininity and physical prowess. ${ }^{17}$

Both Kyle and Peters were engaged in activities that challenged the rituals and conventions of daily life. After all, the female sex was deemed less physically competent, demonstrated by the fact that Kyle could only participate in the Olympic 100 and 200 metres up to 1960. The 400 and 800 metres were first introduced as Olympic events for women in 1964, as was the women's pentathlon, subsequently replaced by the heptathlon in 1981. Indeed, it has been noted that women's involvement in track and field athletics, and in the Olympics, was constrained by the mutually reinforcing beliefs that women were unsuited for vigorous

\footnotetext{
${ }^{14}$ Irish Independent, November 17, 1956

15 Tom Inglis, Truth, Power and Lies (UCD Press: Dublin, 2003).

${ }^{16}$ Interview with Shauna Kyle.

${ }^{17}$ Interview with Mary Peters.
} 
competition and should only participate in female appropriate events. ${ }^{18}$ The expansion of the Olympic programme for women since the 1970s has also reflected changing norms around female athleticism and physicality, seen especially in the introduction of power and strengthbased sports. Despite growing sporting success, sportswomen remained on the margins, however. Sport did not bring honour to women in the same way as it did men, who availed of the networking benefits open to them, off the field of play and in the corridors and boardrooms. As a result, sportswomen were excluded in real and symbolic terms: from getting a favour done by others, from obtaining permission or resources for the development of women's sport, or even getting a job, all of which was available to men who had gained cultural capital through sport.

Public honour is especially relevant to sport: the respect that comes from holding cultural capital. It is accumulated not solely from what you do, but what you then have, who and what you are. It comes from occupational position, property, wealth and education; from being recognised as different and successful, whether by virtue of sex, kin or socially valued services to the community. Public honour marks a person out not merely as being different but, crucially, as superior. Anthropological studies show that public honour is often associated with gender and sex and most link a woman's honour to her modesty, purity and chastity. ${ }^{19}$ Therefore, when dishonour was brought on one woman, it was to all women involved reciprocally in her honour. But in modernising Ireland, north and south, people, especially women, began to have more alternatives: to work; to have more diverse social relations; to believe in one, other or no Gods at all; to rear children with or without a partner; and to express their physicality in more and varied ways. ${ }^{20}$

When Maeve Kyle's honour was challenged that Sunday morning, she was skilful in her riposte. She already had an intuitive second nature understanding of her personal honour, built on her class background, that she transferred into her sporting interests: she was the daughter of the headmaster of Kilkenny College, born into a family of long distinguished service. Her mother was a natural science gold medallist. Her grandfather was provost in Trinity, and a grand chess master whose many regular opponents included Eamon De Valera. She lived with her grandparents while at Trinity, benefiting from the company of the family butler to and from university. Maeve was already a teacher and successful sportswoman before the Melbourne Olympics in 1956, having represented Ireland in hockey and named in the World All Star team in 1953 and 1959. She was the first Irish female athlete at the Olympics an athletic suffragette of sorts. All in all, she had already a strong sense of personal honour and became immersed, through the Ballymena and Antrim Athletic club, in the struggle for public honour for all female athletes. She was skilful and often assertive at stretching what was regarded as permissible, whether in the context of women's athletics or in negotiating the politics of identity in athletics, north and south. ${ }^{21}$

But she still faced public struggles. Her conservative parents-in-law were less than enamoured at her Olympic involvement: they never congratulated her. 'Unusual for women' was the description used by De Valera, ${ }^{22}$ whom she met after a college race at Trinity. For when the struggle for honour is not among equals there are other questions to consider: who legitimates power, and why? With little formal equality between men and women in sport historically, women's identities were constrained by the Irish state's enshrining of their role as

\footnotetext{
${ }^{18}$ Wayne Wilson, “The IOC and the Status of Women in the Olympic Movement: 1972-1996," Research Quarterly for Exercise and Sport 67, no. 2: 183-192.

${ }^{19}$ Inglis, Truth, Power and Lies.

${ }^{20}$ See, Carole Holohan, Reframing Irish Youth in the Sixties (University Press: Liverpool, 2018).

${ }^{21}$ Denis O'Hara, The Remarkable Kyles (O’Hara Publications: Martinstown, 2006).

${ }^{22}$ O'Hara, The Remarkable Kyles.
} 
mothers in policy and legislature. Moreover, sportswomen were branded as outsiders, and even inferior: to other women and to men. They were denied public honour and any chances to respond to this unless and until they were able to demonstrate exceptional success, through their own limited ways and means. Even this was often regarded as inferior.

The process of greater integration and equality between the sexes was slower in Ireland than internationally. For instance, the marriage bar was not removed in the Irish civil service until the 1970s, though it was lifted in 1957 for primary teachers. Changes to equal pay legislation, maternity leave and reproductive rights did not occur until the 1990s. Yet middleclass, white men have managed to maintain a stranglehold on what it means to be a man or a woman. ${ }^{23}$ The 1994 Women's Rugby World Cup (the second of its kind) was retitled Women's Rugby World Championship that year because the then International Rugby Board (IRB) refused to endorse its status, a position that remained until 2009. Rather than being held in Holland as planned, it was moved to Scotland at 90 days' notice and hosted by a small group of Scottish women who, determined, collectively, and without official IRB sanctioning as a world cup, to keep the opportunity alive. This was the first international tournament for the Irish women's rugby team. The message that success had to come before respect and formal investment was often conveyed to this and other teams since, and it remains a consistent message today. While it might be a strong motivational message it minimises the prevailing inequity that exists. Why? Because there have been many women's successes that were not followed by honour and respect. This is changing however, as the current generation of sportswomen seek to understand their own history.

In the multitude of stories that are now beginning to be communicated about women in sport, it is important that this history does not go stale. Women strove to achieve equality in the workplace, education, health, social welfare, at home, before the law and in the way they were portrayed as athletes. The honour and respect of others was and is fundamental to our social being and our sense of self. It is not a coincidence that the social space for women's sports stories has gradually opened up today as a result of the struggles of others. It was the struggle for social, political and economic emancipation - against patriarchal conditioning especially in the 1960s and 1970s - that enabled these stories to be told a generation later. And of course, this was connected directly to first-wave feminism and the negotiation of prevailing expectations of womanhood in the 1920s and 1930s. As Conor Heffernan's paper in this issue also shows, some forms of exercise were popular and liberating, even if the Irish branches of the Women's League negotiated the tightrope of changing social mores. So, too, did the women's football/soccer players who competed against France in 1936, as illustrated in other contributions here (see Gibbs and Faller) and in the factory teams of the 1930s and 1940s. And though Íde Bean Uí was regarded as controversial in her time, her policy of protecting officer roles in camogie for women only ensured a steady line of trained officers for the Cork Camogie Board throughout the 1950s, 1960s and 1970s (see O'Donovan in this issue).

Those who challenged the prevailing expectations - whether in relation to the marriage ban in the civil service, contraception or motherhood outside marriage - were vilified, and in some cases had to be rescued from society. ${ }^{24}$ The fear and shame of becoming pregnant outside marriage was very palpable and passed from mother to daughter. We are living through this legacy in relation to the Mother and Baby Homes Commission of Investigation, for example. ${ }^{25}$ Against this backdrop, and in the knowledge that sportswomen were inferior, especially

\footnotetext{
${ }^{23}$ Katie Liston and Mary O'Connor, "Media Sport, Women and Ireland: Seeing the wood for the trees," in Sport, the Media and Ireland, eds. Neil O’Boyle and Marcus Free (Cork University Press: Cork, 2019), 271307.

${ }^{24}$ Inglis, Truth, Power and Lies.

${ }^{25}$ Paul Jude Redmond, The Adoption Machine (Merrion Press: Dublin, 2018).
} 
because they did not conform to traditional sex roles, women's footballing organisations were formally established on the island in the 1970s. There was the Women's Football Association of Ireland, the Ladies Gaelic Football Association (see Kilgallon in this issue), the Northern Ireland Women's Football Association, and some 20 years or so later came the Irish Women's Rugby Football Union. These were not always received warmly or as sports in their own right because of the gender of those who competed.

Put simply, they were not honourable. They were even shameful, involving women who did not know their place, whose sporting interests and sexual desires were even labelled as deviant. As far as we can tell, they were also formally disconnected from the movement for civil/equality rights, and therefore women's involvement in these traditional male preserves was, for the main part, not a coherent island-wide movement. These were women on the margins as it were. This is not a criticism of those involved - quite the opposite. It is to recognise the scale of the mountain that had to be climbed because of the structures of power within which these sportswomen had to operate, and the extent to which their resilience and perseverance was shown, with the benefit of hindsight, to be a key enabler for the opening up of the sport space to subsequent generations of girls and women.

Women were more inclined to adopt the legitimated and dominant language about themselves in order to advance socially, e.g., when they had to specialise in the logic of marriage and the sphere of consumption. But, what of today? Almost half of married women work, and more than three in ten mothers are not married. Yet they are still defined by gender in the world of work and by their potential for motherhood, even if they are not mothers or have any intention of being so, through job segregation, unequal pay and poorer access to leadership positions. This triple shift - being in paid employment, and engaged in domestic and 'emotion work' in andrarchal societies ${ }^{26}$ - involves a transformation of self: of the way women understand themselves, but also of how communities understand them. And in that transformation, we bear the legacy from one generation to the next. There are particular expressions of this legacy on the island of Ireland. Our forebearers who were born before the famine carried a form of survivor's guilt or, if they were planters/landed gentry and aristocrats, a potentially different form of class-based guilt, born of land ownership, the exclusion of tenant rights and blame focused on the ascendancy. ${ }^{27}$ Their children inherited the guilt of the Civil War that has since fuelled political rivalries, the disillusionment that followed independence, the gerrymandering of political and economic spheres and a divided social life in Northern Ireland. The generation that came of age in the 1960s and 1970s were doomed in many ways to be witnesses or participants in the Troubles. And, though some claim that those now aged under 25 are the first generation on this island to be 'guilt free', this is not borne out by the legacy of intergenerational trauma in Northern Ireland, for instance. ${ }^{28}$ We also need to explore whether we bear any guilt regarding women's sports, a collective inheritance that has perhaps been given less conscious attention up to now.

For if the institutionalised values in sports, like physical strength, stamina, swiftness, skill, athleticism, playing hurt (which brings its own issues) and camaraderie are thought of as human rather than exclusively masculine, the prospect for women's sports is different today

\footnotetext{
${ }^{26}$ Jean Duncombe and Dennis Marsden, "Workaholics and 'Whingeing Women."”

${ }^{27}$ Cormac Ó Gráda, "Eating People is Wrong: Famine’s Darkest Secret?,” January 31, 2013. Available at SSRN: https://ssrn.com/abstract=2209806 or http://dx.doi.org/10.2139/ssrn.2209806; Colm Tóibín and Diarmuid Ferriter, The Irish Famine (Profile Books: London, 2001).

${ }^{28}$ Miles Hewstone, Ed Cairns, Alberto Voci, Frances McLernon, Ulrike Niends and Masi Noor, "Intergroup Forgiveness and Guilt in Northern Ireland: Social Psychological Dimensions of 'The Troubles," in Collective Guilt: International Perspectives, eds. Nyla Branscombe and Bertjan Doosje (Cambridge: Cambridge University Press, 2004), 193-215.
} 
than in the past. But this is a challenge because of the incomplete histories and understanding of women's involvement in sport. To know ourselves we have to face ourselves, and what happened in the past. And while it is important sometimes to let go of history in some places, at other times and in other places it is appropriate to keep one eye on the past. What then of the ongoing struggle for honour for women's sports and the topical question of gender quotas?

\section{Honour, Shame and Quotas}

Prior to the introduction of the first Women in Sport Policy, by Sport Ireland in 2019 (see Stapleton in this issue), there was an incoherent, disjointed and arguably ad hoc approach to gender equality in sport. Late twentieth-century developments in this field confirm this. When I co-wrote with Gina Menzies the Joint Oireachtas Committee Report on Females in Sport in $2004,{ }^{29}$ we had one aim: not to repeat a mistake that was made some years prior. This was a 1998 call for submissions on women in sport, led by then Minister for Sport, Bernard Allen. I kept a watching brief on this 1998 call, which was chaired by Gina, herself a former international squash player. Interested in interviewing her for my own doctoral thesis, it became clear to me that the 1998 submissions had in fact fallen by the wayside, lost in the emergence of the Irish Sports Council in 1999 (now Sport Ireland), which was the new state-funded body for sport, and the desire for organisational power, control and autonomy that came with this. The 1998 Women in Sport Taskforce produced a report that was never published, despite numerous submissions being made. When it came to the possibility of a Joint Oireachtas report some years later, Gina and I were determined that the voices of women would this time not be consigned to the tramlines.

There was no coherent strategy around whom was to formally present to the Oireachtas committee and why, and it seemed, speaking to Gina, that 'a few women would be enough' to fulfil the committee's objectives. Gina presented to them, as did Maeve Kyle and Debbie Massey (then CEO of Basketball Ireland). Together Gina and I wrote the final report that was submitted to the Oireachtas member then leading this special interest topic, Jimmy Deenihan (also a former Kerry footballer). Then and now, sport was not a big-ticket issue for politicians, but Deenihan was adept at transforming cultural (i.e., sportive) to political capital, a pattern that appears to prevail in Ministerial sport appointments since. There were four overarching terms of reference:

To review the development of key issues since the 1998 Taskforce Report and collate existing Irish and international research on these issues;

To assess any changes since 1998;

To gather submissions from interested parties on central issues related to females' participation in sports and physical activities, and;

To establish realistic and actionable recommendations based on a review of existing research as well as any issues that national governing bodies of sport face in the provision of female sports.

Politically, this report was consigned to the policy sidelines, contributing to many unanswered questions about its purpose from those who knew of its existence then, and now. Though the Joint Committee felt that it was politically timely to examine the situation of women in sport, in practice there was no widespread political or social commitment to act on the report. Gina and I prepared 23 recommendations and an additional comment was added to our draft to

\footnotetext{
${ }^{29}$ Joint Committee on Arts, Sport, Tourism, Community, Rural and Gaeltacht Affairs. Report on Females and Sport. Dublin, 2005. http://archive.oireachtas.ie/2004/REPORT_20040701_0.html.
} 
indicate that the committee (or perhaps Deenihan) did not necessarily agree with one recommendation - concerning the need for a Women's Sports Foundation.

Following the completion of our draft report in the final quarter of 2004, a Women in Sport Conference was held in Croke Park in October 2005. The timing of the report seemed to place the Oireachtas Committee, and the committee member leading this, as beneficiaries of honour, playing into a government announcement in December 2004 of the first dedicated funds for women in sport. This funding was allocated to the Irish Sports Council (now Sport Ireland) to women in sport programmes, who seemed unaware of the Joint Oireachtas report, and who had themselves commissioned research by the Economic and Social Research Institute into sports participation, though not on women in sport per se. Separately, the same Joint Oireachtas Committee also produced a report on Volunteering in Ireland in January 2005, which recommended greater investment into volunteer capacity and capability, including sport. It is difficult to ascertain whether the Joint Oireachtas report on Women in Sport, which was profiled at the October 2005 Conference was a symptom of this policy shift or if the first formal funding injection for women in sport was in fact spurred on by its release. Policy incoherence regarding gender equality in sport was evident however in the fact that the Irish Sports Council was apparently unaware of the Joint Oireachtas report.

Some of the other recommendations were: the appointment of a fulltime Women's Development Officer (a role first created in 2019 and filled by Nora Stapleton, who has also contributed to this issue); an annual women's sports award scheme, which was taken up separately by National Governing Bodies (NGBs) and print broadcasters alike; longitudinal research on the depth, breadth, types and content of media coverage of women's sports (which is not yet acted upon and was highlighted again in the 20x20 campaign); and the need for gender equality strategies in all sports, including gender balance on all decision-making committees. This has since been taken up by the Women in Sport Committee, established by Sport Ireland in 2019.

To be clear: there is no claim that the 2005 Oireachtas report led directly to the outcomes that we are seeing some 15 years later. Correlation and causation are not the same thing, and state policy on women in sport was conspicuous by its absence in the early 2000s. Rather, this example illustrates that the struggle for honour is an ongoing one, even today, in which we negotiate the legacy of the past. Today, the question of gender quotas has become a hot topic internationally, and in Ireland, beyond and within sport: hot, because it has been both misrepresented and misunderstood; misrepresented for promoting so-called unqualified women above men and misunderstood for ignoring the inherent inequalities that uphold meritocracy as a universal principle.

We have, in my view, inherited the guilt of previous generations regarding the gender gradient in sport and this has influenced the public debate on gender quotas in sport thus far. The approach to quotas is ill informed, not only from NGBs, some of whom have pushed back against the suggestion, but also from some sportswomen themselves. It is as if in the desire for perceived equality, the current generation do not wish to be associated with quotas, that might involve changes in the recruitment and appointment structures for committees and include targets for a minimum number of females. Why? Because such an approach would not be honourable. In this view, honour is conflated with merit, which when stripped of its context is regarded as a universal principle. But this view is bereft of a historical sensitivity to the fact that merit has always and everywhere existed, but it is inevitably shaped and constrained by social conditions. Maeve Kyle achieved much based on merit even when males dominated sports leadership roles. The Irish women's rugby team too achieved notable successes, in the second decade of the twenty-first century, yet were comparatively under-resourced and 
unsupported in this regard. O'Donovan (in this issue) also highlights the challenge for Cork Camogie in gaining access to playing pitches, and the subsequent restriction on skill development. The discussion on quotas in Ireland thus far also appears to conflate positive action with a lack of fairness. ${ }^{30}$ The various responses to the idea of quotas illustrate this as does the legitimate language around it: women do not wish to be tokens appointed before men. This ignores the fact that, in our collective past, women who were equally if not more qualified than men were often not appointed on their own merit. Yet others would say that it is better to bring about change slowly and organically and that it should not be foisted on those who resist it most. We might offer a more or less generous interpretation of this ongoing resistance, but, that aside, the more important point is that behind calls for slow organic change, without compulsion, is the assumption that progress has occurred in a linear fashion, from an unknown starting point in past to the present day. This does not deal with the reality that equality has not, and does not automatically, follow female trailblazers. In other variants of the quota debate, time is sufficient for bringing about change, and therefore voluntary non-compliant targets are better than quotas. This response seems questionable at best in light of the evidence, in Ireland and internationally, which illustrates the deep-seated and longstanding gender imbalance in sport, on and off the field and courts of play.

In discussions about how best to promote women into sports leadership, public and private honours appear to be uncomfortable bedfellows. The case for diversity is strong, in financial and productivity terms, but less so morally it appears. This seems rather short-sighted when the international evidence suggests that quotas have positive effects. For instance, rarely has a less qualified female been appointed above a more qualified male. In other words, exceptional candidates will excel. Quotas can add value and work effectively, provided they occur in conjunction with gender equity as an organisational value, the sharing of influential board roles and portfolios amongst men and women, and the creation of a cohesive leadership team.

Since there is a choice about what to include and what to omit in the stories that we tell, and how we tell them, the stories of women in sport are especially important. They help us to understand not only how things were different, but also the legacies which remain in the way we see the world and ourselves. We can better understand how we came to be the way we are, and therefore to see many possible futures. Through increased equality between the sexes, through critical reflection, and through retelling these stories, we can see how power elites operated to ensure that sporting honour was largely a male preserve. In teaching the current generation about this, it is important that we help them appreciate that today's opportunities are directly connected to yesterday's struggles. Merit is honourable, personally, but equally, quotas are by no means shameful in public struggles. Hopefully we can all work towards a future where the desire for equality might overcome the will to power.

\footnotetext{
${ }^{30}$ For further insight into quotas, see M. L. Krook, Candidate gender quotas: a framework for analysis'; D. Dahlerup and L. Freidenvall, 'Quotas as a fast track to equal representation for women'. For a forthcoming discussion on gender and sports governance on the island of Ireland, including the most debates on quotas there, see K. Liston, Gender, Governance and 'Ireland': (In)visibility and Symbolism'.
} 


\section{Bibliography}

Cone, Carl, ed. Hounds in the Morning: Sundry Sports of Merry England. Lexington: University Press of Kentucky, 1981.

Dahlerup, Drude and Lenita Freidenvall. "Quotas as a fast track to equal representation for women: Why Scandinavia is no longer the model." International Feminist Journal of Politics 7, no. 1: 26-48.

Duncombe, Jean and Dennis Marsden. “'Workaholics' and 'Whingeing Women': Theorising Intimacy and Emotion Work - The Last Frontier of Gender Inequality?" The Sociological Review 43, no. 1: 150-69.

Guttmann, Allen. Women's Sports: A History. New York and London: Columbia University Press, 1991.

Hewstone, Miles, Ed Cairns, Alberto Voci, Frances McLernon, Ulrike Niends, and Masi Noor. "Intergroup Forgiveness and Guilt in Northern Ireland: Social Psychological Dimensions of 'the Troubles'?" In Collective Guilt: International Perspectives, edited by Nyla Branscombe and Bertjan Doosje, 193-215. Cambridge: Cambridge University Press, 2004.

Holohan, Carole. Reframing Irish Youth in the Sixties. Liverpool: Liverpool University Press, 2018.

Inglis, Tom. Truth, Power and Lies: Irish Society and the Case of the Kerry Babies. Dublin: UCD Press, 2003.

Jennings, L. A. She's a Knockout!: A History of Women in Fighting Sports. London: Rowman \& Littlefield, 2015.

Joint Committee on Arts, Sport, Tourism, Community, Rural and Gaeltacht Affairs. Report on Females and Sport. Dublin: 2005.

Krook, Mona Lena. "Candidate gender quotas: a framework for analysis." European Journal of Political Research 46, no. 3: 367-94.

Liston, Katie. 'Gender, Governance and "Ireland": (In)visibility and Symbolism', In Gender Equity in UK Sport Governance, edited by Lucy Piggott and Philippa Velija, Chapter Five (forthcoming). London: Emerald (Studies in Sport and Gender Series). 2021

Liston, Katie and Mary O'Connor. "Media Sport, Women and Ireland: Seeing the wood for the trees." In Sport, the Media and Ireland: Interdisciplinary Perspectives, edited by Neil O’Boyle and Marcus Free, 271-307. Dublin: Cork University Press, 2019.

Miller, Ben. Irish Swordsmanship: Fencing and Duelling in Eighteenth Century Ireland. New York: Hudson Society Press, 2018. 
Ó Gráda, Cormac. “Eating People is Wrong: Famine’s Darkest Secret?” January 31, 2013. Available at SSRN: https://ssrn.com/abstract=2209806 or http://dx.doi.org/10.2139/ssrn.2209806;

O’Hara, Denis. The Remarkable Kyles. Martinstown: O’Hara Publications, 2006.

Redmond, Paul Jude. The Adoption Machine: The Dark History of Ireland's Mother and Baby Homes and the Inside Story of how Tuam 800 became a Global Scandal. Dublin: Merrion Press, 2018.

Santayana, George. The Life of Reason: Reason in Common Sense. Cambridge: Harvard University Press, 1905.

Smith, Malissa. A History of Women's Boxing. Plymouth: Rowman \& Littlefield, 2014.

Thrasher, Chris. "Disappearance: How shifting gendered boundaries motivated the removal of eighteenth century boxing champion Elizabeth Wilkinson from historical memory." Past Imperfect 18 (2012). Available at https://doi.org/10.21971/P7SK56.

Tóibín, Colm and Diarmuid Ferriter. The Irish Famine. London: Profile Books, 2001.

Wilson, Wayne. "The IOC and the Status of Women in the Olympic Movement: 1972-1996." Research Quarterly for Exercise and Sport 67, no. 2: 183-92. 